Sustainability Agri, Food and Environmental Research 4(4), 2016: 45-49

ISSN: 0719-3726

\title{
Key for Microzooplankton Species found in Sundaparandian
}

\section{Pattinam and Manamelkudi, Tamil Nadu, India (9-10 N, Arabian Sea).}

Mariadoss Kalaiarasi $^{\mathrm{a}}$, Periyasamy Ambikadevi ${ }^{\mathrm{b}}$, Jayaseelan Bharath ${ }^{\mathrm{a}}$, and Chelladurai stella ${ }^{\mathrm{a}, *}$

${ }^{a}$ Department of Oceanography and Coastal Area Studies ,AlagappaUniversity, Thondi Campus623409,Tamil Nadu ,India.

Corresponding author, email: stella2004@rediffmail.com

${ }^{\mathrm{b}}$ Arignar Anna.Govt. Arts\&Science college, Karaikal -609605

The present note consists of a single key for microzooplankton identification. Their classification is presented below following Edmondson classification (1959), Davis (1955) and Omeri and Ikeda (1984). Key to the copepod given here are modified from Kasturirangan (1963) and Newell and Newell (1973). Taxonomic Account of Microzooplankton occurring in S.P. Pattinam and Manamelkudi During July 2005 to June 2006.

Key to the major groups of planktonic animals

1. -One celled or many celled, all cells are more or less alike .... Phylum: Protozoa (2)

Many celled with different kinds of cells

2. Cells possessing flagella or pseudopodia; Cells possessing cilia ..... Class: Infusoria (3)

3. Cells possessing flagella .... Class: Mastigophora

Cells possessing pseudopodia .... Class: Sarcodina

4. Cells with a central capsule or shell or lattice work composed of spicules.... order: Radiolaria Without a central capsule but with a shell or test.... order: Foraminifera

Without shell or testor capsule.... order:Amoebaea

5. Without organ systems .... (6)

With organ systems, some at least developed .... (7)

6. Cells forming a ball with flagellated cells at one pole and non-flagellated flat cells at the other pole .... Phylum:Porifera

An external layer of ciliated cells covering large endodermal cells ..... Phylum:Coelenterata (Planula)

7. Radially or biradially symmetrical forms 
Sustainability Agri, Food and Environmental Research 4(4), 2016: $45-49$

ISSN: 0719-3726

Bilaterally symmetrical forms or asymmetrical

8. Radially or biradially symmetrical forms .... Phylum:Coelenterata

Biradially symmetrical forms with eight rows of ciliary combs arranged the length of the body .... Phylum: Ctenophora

9. With a vertebral column or a notochord or both .... Phylum: Chordata (10)

With neither a vertebral column nor a notochord

10. With a vertebral column .... sub Phylum: Vertebrata

With a notochord only

11. Notochord confined to the tail region .... sub Phylum: Urochordata

Notochord extends the length of body .... sub Phylum: Cephalochordata

12. Body segmented with exoskeleton with paired appendages or setae .... (13)

Body not segmented wormlike with paired lateral fins .... Phylum: Chaetognatha

Body not segmented with exoskeleton or lorica and setae are not paired but later ....

Phylum: Rotifera

Body not segmented with thick cuticle and setae .... Phylum : Nematoda

13. Body wormlike with paired lateral setae ....

Body segmented with paired appendages .... Phylum:Arthropoda

14. Carapace forming a bivalved shell covering the entire body and having head ... (15)

Carapace forming a bivalved shell covering the entire body and no head ... Class: Bivalvia Carapace circular and coiled carapace not thus ...... Class:Gastropoda (16)

15. With a well-developed cement gland .... Sub class:Cirripedia

Without a well-developed cement gland .... Sub class:Ostracoda

16. Three pairs of segmented appendages .... Class:Crustacea

With more than three pair of appendages.... (17)

17. Carapace forming a bivalved shell which does not cover the head...Class: Crustacea; Order:

Cladocera

Carapace not thus

18. Carapace small not covering the last five thoracic segments .... Order: Cumacea without carapace.... (19)

19. Most of the thoracic appendages are uniramous and leg like .... (20)

Most of the thoracic appendages are biramous and swimmeret like .... sub class: Copepoda

20. Body usually flattened dorsoventrally; thoracic legs of one kind .... Order: Isopoda Body flattened laterally; thoracic legs more than one kind ..... Order: Amphipoda 
Sustainability Agri, Food and Environmental Research 4(4), 2016: 45-49

Key to microzooplankton

Class: Rhizopoda

Order: Formaninifera

Test is spiny consisting of 5.6 chambers per whorl. The final chamber often forms a flap like extension..... Globigerina quinqueloba.

The test is small and highly lobate. It is spired with 3.5 to 4 chambers in the last whorl. The wall is finely perforated. These are 12 chambers which are spherical and arranged In $2 \frac{1}{2}$ whorls. The sutures are distinct and depressed ...... Globigerina parva.

The test is free and composed of rapidly enlarging chambers arranged trochospirally. The chambers are subglobular and arranged in two whorls: the last whorl comprises 3 chambers. The wall is calcareous and coarsely perforated. The sutures are distinct and depressed..... Globigerinatriloculinoides.

Test consisting of a number of small chambers, all chambers visible and test coarsely perforated ......... Globigerina rubescens .

Order: Acantharia

The length of the spicules is 400-600 and approximately 3 thick projecting from a protoplasm of 160-250 diameter ...... Acanthochiasma fusiforme.

Spicules are present. It looks like a spider web.... Acanthometron Species.

Class: Ciliata

Order: Tintinnida

Lorica consisting of a bowl with or without an aboral horn: oral region with or without a flare: wall composed of a fine primary structure and agglomerated material ...

\section{Tintinnopsis}

Lorica is more cylindrical, elongated without bowl ending in an aboral horn.... T. cylindrical.

Irregularly shaped posterior margin Agglomeration is moderate.... T. nordquisti

Lorica with two regions bowl and a column without oral flare.

Bowl and column uniformly agglomerated ..... T.tubulosa.

Lorica without aboral horn

Lorica with small oral flare and oral rim irregular.... Tintinnopsis directa.

Lorica is shorter and has a short and rather broad pedicel aborally ..... T. strigose. 
Sustainability Agri, Food and Environmental Research 4(4), 2016: 45-49

ISSN: 0719-3726

Lorica is small and closed at its aboral end and has few particles attached to it ... $T$. acuminate.

Lorica with one main region

Lorica bullet shaped .... T. beroidea

Lorica is widely open trumpet-shaped oral end.

The aboral end is closed..... T.campanula.

Lorica is of variable form with the blunty pointed aboral end..... T. lobancoi.

Lorica with aboral horn, column and spherical bowl, bowl between a long column and horn ..... T. tocantinensis.

Lorica tubular or sack shaped, aboral and closed or open, wall soft, very minute foreign particles on lorica ..... Tintinnidium

Lorica soft with sparse agglomeration and open aboral end ..... T.primitivum

Lorica soft with sparse agglomeration and closed aboral end ..... T.incertum

Lorica more or less cylindrical, open at both ends coarsely agglomerated .... Leprotintinnis

Lorica with an opening on both ends, slight constriction near the aboral end.

The walls of lorica are soft ....... L..pellucidus)

Lorica with openings on both ends Lorica with large aboral flare ..... L. nordquisti

Lorica with bowl and windows.... Dictyocysta

Lorica is penetrated by three whorls of fenestrae ..... D.elegans

Lorica without spine .... D.seshaiyai

Lorica with agglomerated bowl and hyaline collar.... Codonellopsis

Collor has spiral markings, shorter than the main bowl of the lorica..... C. pusilla

Collor is longer than the bowl..... C.ecaudata

Long collor with avoid fenestrate bowl without pedicel.... C.ostenfeldi

Lorica without agglomerated particles ..... Favella

Lorica is composed of primary and secondary reticular elements.

Lorica with aboral horn and without spiral turns ..... Favella philippinensis

Lorica with less than four spiral turns, horn with wings ... F. ehrenbergii

Lorica is small and clean with aboral end.

Lorica with 8 spirals turns ...... Helicostomella longa 
Sustainability Agri, Food and Environmental Research 4(4), 2016: 45-49

ISSN: 0719-3726

Lorica is clean and slender. Lorica has a slight flare and it is provided with straight striations .....Rhabdonella sp. (Fig: 30)

Lorica is short with aboral end.

Collor is also short with 2 annuli..... Metacylis jorgensenii

\section{REFERENCES}

Davis, C. C., 1955. Plankton. Western Reserves University.

Edmondson, W. T., 1974. Secondary production. Mitt. Internat. Verein. Limnol. 20 : 229-272.

Kasthurirangan, L. R., 1963. A key for the identification of the more common plank tonic copepod of Indian coastal waters. CSIR, New Delhi.

Newell, G.E. Newell, R.C., 1973. Marine Plankton, a practical Guide Hutchinson education Co, Ltd., London.

Omori, M., Ikeda, T. 1984. Methods in marine zooplankton ecology. "A Wiley-Inter Science Publication John Willey \& Sons. Japan. 332 pp. 